\title{
From Traditional to Strategic CSR: Systematic Literature Review
}

doi: http://dx.doi.org/10.12775/JCRL.2020.003

\author{
MiKOŁAJ ŚLĘZAK \\ The Faculty of Economic Sciences and Management, Nicolaus \\ Copernicus University in Toruń, Poland \\ e-mail: mikolaj.slezak@wp.pl
}

\begin{abstract}
The idea of corporate social responsibility (CSR) is a very significant element of companies and societies functioning. Literature exemplifies that this concept still becomes more and more popular. Considering it from the strategic perspective can be a driver for businesses success. This article focuses on the CSR concept and its different aspects. The aim of the paper is to describe and exemplify the issue of the corporate social responsibility concept, with the focus on its strategic aspects. In order to achieve the aim of the paper, there have been set the following objectives: (1) to discuss definitions of the CSR concept, its origins, drivers and different types; (2) to present strategic CSR definitions, its benefits and dimensions; (3) to exemplify how to embed the CSR concept into strategy; (4) to discuss the complexity of the strategic approach to CSR. The study is based on the systematic literature review. At the beginning, the article presents the method of the study and the research sampling process. The next step of the study outlines the CSR concept and its definitions and key assumptions. Later, the article exemplifies the strategic approach to the CSR concept. The study confirms the significance of converting CSR activities into strategies and linking them with the grand strategy of companies. Nevertheless, there is still a big need to investigate this issue more deeply in order to have a better and more comprehensive view on that.
\end{abstract}

Keywords: corporate social responsibility, CSR, strategic CSR, strategic management, systematic literature review. 


\section{Introduction}

The idea of corporate social responsibility (CSR) has become more and more popular and significant in recent years, both for researchers and businesses. The number of publications about this concept is still growing. CSR should be taken into account by managers, who want develop their companies throughout a sustainable growth. A very important aspect regarding the CSR concept is an appropriate placing of this idea into the firm's strategy. Effective implementing and managing of CSR strategies and incorporating them into companies' strategies can produce a lot of benefits. Sometimes, CSR becomes even a priority for some managers, who are aware of importance of this idea. The concept of corporate social responsibility is very wide and complex. It has been a subject of firms' and academia's interest for many years. At the beginning, this considerations were focused mainly on business' responsibilities towards societies and the environment. Later, they were deliberated influences of these actions on companies' performance. Nowadays, the issue of building and incorporating CSR strategies into companies' strategies becomes more and more significant (Galbreath, 2009). Managers pay more attention to the strategic role of CSR and its influence on the whole organizations (McWilliams et al., 2006). The strategic role of corporate social responsibility concept is also a subject of this study.

Undoubtedly, the CSR concept can be already considered as one of the most important aspects of functioning of today's businesses. The idea of corporate social responsibility attracts also a lot of researchers and academia studying this concept. Thus, in the literature there can be found a lot of studies, which deal with this topic. Nevertheless, still there can be identified some gaps and areas which are not studied as thoroughly as others. In the author's opinion one of these gaps can be the strategic approach to CSR. The author believes that this study can be valuable and very useful contribution in the process of developing of the CSR concept.

The aim of the paper is to describe and exemplify the issue of the corporate social responsibility concept, with the focus on its strategic aspects. In order to achieve the aim of the paper, there have been set the following objectives: (1) to discuss definitions of the CSR concept, its origins, drivers and different types; (2) to present strategic CSR definitions, its benefits and dimensions; (3) to exemplify how to embed the CSR concept into strategy; (4) to discuss the complexity of the strategic approach to CSR. 
The structure of the article is as follows. It starts with this introduction. Then, it is provided the methodological section, where the systematic literature review and the research sampling process are explained. Later, there is presented the CSR concept, together with its definitions, origins, drivers and different types of CSR. Then, the article provides the definitions of strategic CSR, along with the benefits and dimensions of this idea. Then, there is explained how to incorporate the CSR concept into strategy and there is also summarized the complexity of the strategic approach to CSR. Finally, the article ends with a conclusion section, which is a summary of all the most important information described in the article.

\section{Method of study}

The systematic literature review methodology was chosen and applied as a main method of the study, as it seems to be the most effective way to meet the objectives of this kind of studies (Czakon, 2011). This methodology becomes more and more popular among academia. It is also often used by authors publishing their studies in Journal of Corporate Responsibility and Leadership (Czerniachowicz et al., 2017; Józefowicz, 2017; Ślęzak \& Jagielski, 2018). The works by Czerniachowicz et al. (2017), Lis (2017), and Lis and Sudolska (2018) were used as benchmarks in the study design processes.

The literature review included 12 publications, recognized as the most relevant to the topic. The research sampling process was divided into four steps as presented in Table 1.

Table 1. Research sampling process

\begin{tabular}{ll}
\hline Stage & Publications [N] \\
\hline Records identified in the Scopus database through title search & 385 \\
\hline Records identified through limiting the subject area & 286 \\
\hline $\begin{array}{l}\text { Records identified through excluding publications of the } \\
\text { number of citations lower than h-index }\end{array}$ & 37 \\
\hline $\begin{array}{l}\text { Records identified through abstract analysis, subject to full-text } \\
\text { analysis }\end{array}$ & 12 \\
\hline
\end{tabular}

Source: own study based on data retrieved from the Scopus database. 
In order to study the issue of the strategic approach to the CSR concept, the publications indexed in the Scopus database, dealing with this subject were identified. The research sampling process was carried out in four steps:

(1) The conjunction of phrases ('CSR' OR 'Corporate Social Responsibility') AND ('strategy' OR 'strategic') was searched in article titles. It was found 385 results;

(2) The results were limited to the subject area of Business, Management and Accounting. The sample was limited to 286 results;

(3) It was checked the h-index which was equal to 37 . Thus, only publications with the number of citations equal or higher than 37 were taken into account. It was left 38 results;

(4) The analysis of abstracts was conducted in order to identify the most relevant papers for full-text analysis. The sample was reduced to 12 publications

\section{Definition and key assumptions of the corporate social responsibility concept}

For years, the corporate social responsibility concept has been the subject of the debate among both business practitioners and academia. Firstly, this discussion focused mainly on business' obligations towards societies and companies' social responsibilities. Later, CSR influence on firm performance was taken into consideration. In recent years and nowadays, it appears more and more questions related to building and incorporating CSR strategies into companies' strategies (Galbreath, 2009). Researchers pay more attention to the CSR strategic role and implications in enterprises (McWilliams et al., 2006). McWilliams et al. (2006), referring to the theory of firm perspective on CSR, state that CSR can be "an integral element of a firm's business and corporate-level differentiation strategies" and should be taken into account while determining the company's strategy as a strategic investment and a form of image improvement. According to Porter and Kramer (2006), CSR becomes inevitable priority for many businesses around the world. They notice that many enterprises have already done a lot in the area of reducing unfavorable effects of their operations and creating additional benefits for societies and the environment. However, their commitment 
in this field is not as effective as it could be. It takes place for two reasons. Firstly, companies run their business against societies, and these areas are interdependent. Secondly, enterprises perceive CSR too generally instead in the most appropriate way for their strategies (Porter \& Kramer, 2006). To better understand the significance of strategic CSR, firstly it is important to introduce the definition of the corporate social responsibility concept and then match it with the company's strategy.

The CSR concept is a very broad term. In the literature, there can be found its numerous definitions, approaches and interpretations. Nevertheless, it is not easy to find and choose one definition, which clarifies entirely the whole complexity of this matter. Consequently, let us look shortly at some of them. McWilliams et al. (2006, p. 1) define CSR as "situations where the firm goes beyond compliance and engages in actions that appear to further some social good, beyond the interests of the firm and that which is required by law". On the other hand, Baron (2001, p. 9), provides a bit shorter explanation of the CSR. For him it is "the assumption and fulfilment of responsibilities beyond those dictated by markets" and "private provision of a public good". Also Siegel and Vitaliano (2007) go out with very similar interpretation of the CSR concept. According to them, it exists when companies commit to progressive social activities beyond that required by law. It is also worth mentioning the CSR definition from the stakeholder perspective, which is provided by Dawkins and Lewis (2003, p. 187): “as a range of stakeholder groups understand it, corporate responsibility entails a company's recognition of broad responsibilities, that it is part of society with consequent obligations, and that it should be concerned with more than just profit". As already mentioned, the CSR concept is a very extended idea and various approaches to and definitions of that issue can be identified. Summarizing all provided definitions, it can be said that CSR is a voluntary concept and is related to activities which produce some benefits for the society. Moreover, companies and the environment in which they operate are interdependent and need to cooperate to create common good.

Firms engage in CSR activities for many different reasons. Some of them include CSR into their operations voluntarily, some of them believe to gain benefits thanks to that. It is also connected with types of CSR, which regard its nature and aims. Baron (2001) claims that enterprises engage in CSR because of their believe to gain more money, for altruistic reasons, or as an answer to stakeholders' expectations. 
On the other hand, Porter and Kramer (2006) observe that increased attention in the area of CSR activities was not fully voluntarily driven. Many companies have noticed the significance of CSR just after increasing social expectations concerning various problems, which earlier did not occur in the area of business activities. As a result of increasing social constraints, a debate about CSR has moved to corporate boardrooms. Moreover, firms pay more attention to societal needs and even publish annual reports regarding their CSR activities. Much more researchers notice that growing social expectations toward business are the strongest drivers for CSR development. Orlitzky et al. (2011) state that enterprises are under constant pressure of various stakeholder groups to engage in CSR. McWilliams et al. (2006) claim that managers are aware that they are under pressure of different social groups (stakeholder groups, e.g. workers, suppliers, local communities, NGOs, governments) to act more and stronger in the CSR area. They link it with Freeman's stakeholder theory (which maintains, e.g. that managers have to meet various stakeholders' needs). According to above, managers should meet these needs to keep good relations with these groups to create benefits for both. Summarizing, it can be found that companies involve in CSR mainly as an answer to social expectations. However, it can create values for both.

In reference to some factors, like drivers, aims, nature of business or activities, various types of CSR can be distinguished. Lantos (2001) enumerates three mutually exclusive types of CSR (referring to their nature and aims):

- ethical CSR: it is morally mandatory and is something more than only economic and legal obligations fulfillment. Its aim is to avoid social harms, even if businesses do not achieve any benefit from this (Lantos, 2001);

- altruistic CSR: it goes beyond enterprises' scope of activities. It is an engagement in activities for a common good. It creates benefits for company's stakeholders, but not necessarily for the enterprise (benefits are uncertain and may be even irrelevant) (Lantos, 2001);

- strategic CSR: it is fulfillment of firm's social obligations in order to achieve a win-win effect, where both companies and at least one group of stakeholders achieve benefits from these activities (Lantos, 2001). An example of a strategic CSR activity can be a situation when enterprises link a common good 
with their own product sales (McWilliams et al., 2006). A case of strategic CSR will be studied thoroughly in the following section.

\section{Strategic approach to CSR}

Relationships between businesses and societies are very relevant for the appropriate functioning of the economy. They need each other and have to cooperate with themselves, taking into consideration their existence and needs. Well understanding and including social responsibility assumptions in companies' strategies is crucial to integrate business environments and societies. However, the most common approaches to the CSR concept are "so fragmented and so disconnected from business and strategy as to obscure many of the greatest opportunities for companies to benefit society" (Porter \& Kramer, 2006, p. 79). Nevertheless, CSR can be "an integral element of a firm's business and corporate-level differentiation strategies" and should be taken into account while determining the company's strategy as a strategic investment (McWilliams et al., 2006).

Strategic CSR is one of the types of CSR. Obviously, in the literature, it can be found many various definitions of this term. Baron (2001) is the first researcher who introduces the idea of 'strategic CSR'. He states that it is connected with a market strategy in order to gain higher profit. The researcher defines strategic CSR as "a profit-maximization strategy motivated by self-interest and not by a conception of corporate social responsibility” (Baron, 2001, p. 9). McWilliams and Siegel (2011, p. 1481) claim that strategic CSR is "any responsible activity that allows a firm to achieve a sustainable competitive advantage, regardless of motive”. Siegel and Vitaliano (2007) identify an inclusion of CSR activities in the company's business-level differentiation strategy as a main assumption of the theory of strategic perspective on CSR. This is a very similar point of view to this presented by McWilliams et al. (2006) that CSR can be a fundamental factor in creating corporate-level differentiation strategies. A significant issue also arises from the study conducted by Perrini et al. (2007). They notice that the company's approach to the CSR strategy differs in large firms and small and medium enterprises. Taking into consideration all presented definitions and approaches, the following one has been chosen as a reference for 
further research: strategic CSR is a fulfilment of firm's social obligations in order to achieve a win-win effect, where both companies and at least one group of stakeholder achieve benefits from these activities (Lantos, 2001). Moreover, a very important task to fully match CSR with firm's strategy is recognition of social issues as strategic issues (Galbreath, 2009).

The milestone in considering and perception of strategic CSR significance can be an article "Strategy \& society: The link between competitive advantage and corporate social responsibility" published in Harvard Business Review by Porter and Kramer (2006). For instance, they propose to change an approach to CSR and underline an importance of including relations with the environment in companies' strategies. Porter and Kramer (2006) emphasize a significance of interdependency between businesses and societies and linking it with firm's strategy. They state that "for any company, strategy must go beyond best practices” (Porter \& Kramer, 2006, p. 87). Moreover, it must be followed by differentiating against competitors in such a way that lower costs and higher quality services would meet particular customers' needs. As noticed by Porter and Kramer (2006)

Strategic CSR must go beyond good corporate citizenship and mitigating harmful value chain impacts to mount a smaller number of initiatives whose social and business benefits are large and distinctive. Strategic CSR involves both inside-out and outside-in dimensions working in tandem. It is here that opportunities for shared value truly lie (Porter \& Kramer, 2006, p. 87).

Strategic CSR allows to create shared value through company's investments in some social activities which enhance competitive advantage. It is related to the interdependence between businesses and societies, because well-being of one depends on the second one and vice versa. "Typically, the more closely tied a social issue is to the company's business, the greater the opportunity to leverage the firm's resources and capabilities, and benefit society (Porter \& Kramer, 2006, p. 87). Enterprises, taking into account social expectations in their strategies, can produce a lot of benefits for both as a result of strategic CSR activities.

Considering CSR as an element of a strategy, it can become a source of society development, only if firms would commit appropriate 
resources, using them in an effective way to activities creating benefits for communities (Porter \& Kramer, 2006). Porter and Kramer (2006) propose a change in an approach to the CSR concept and relate it more closely to business and strategy. It could give many opportunities and benefits for enterprises and stakeholders. They suggest: "if, instead, corporations were to analyze their prospects for social responsibility using the same frameworks that guide their core business choices, they would discover that CSR can be much more than a cost, a constraint, or a charitable deed - it can be a source of opportunity, innovation, and competitive advantage” (Porter \& Kramer, 2006, p. 79).

One of the main aims of strategic CSR management is to evaluate company's CSR activities. It means, the task is, firstly to develop activities that have potential to give benefits to an enterprise, and secondly to reduce those which do not have a positive impact on the firm (Husted \& Allen, 2007).

Successful strategic management of CSR allows firms to take into account legitimate stakeholder claims, focusing and expanding work in those areas where competitive advantage can be created, while assigning appropriate allocation of resources to meet social needs. A secondary benefit of successful CSR strategy is that it encourages firms to seek additional ways in which social action also leads to profit (Husted \& Allen, 2007, p. 595).

McWilliams et al. (2006) analyze various different papers, which regard the topic of relations between CSR and firm performance. However, those studies indicate different relationships: negative, no relation, and positive. It can be an outcome of many reasons, e.g. differences in CSR defining, differences in firm performance defining, the sample size, or differences in time etc. Also Husted and Allen (2007) notice that firm's performance depends on too many variables to assess in an effective way how CSR influences on it. McWilliams et al. (2006) agree with other researchers that empirical studies regarding relations between CSR and firm performance should distinguish between: strategic CSR (stakeholder management) and altruistic CSR (social issue participation). Thus, it can be concluded that there is a positive relation between strategic CSR and firm performance and a negative relation between altruistic CSR and firm performance. Moreover, Husted and Allen (2007, p. 595) propose "re-confirming non-market 
social activities as social-market activities as a necessary first step in exploring how to manage CSR for value creation”. They state that it is in line with a well-established idea in strategic management that it is more probable that company's activities bring value creation if executives look for gaining competitive advantage while designing their projects.

A very interesting approach to strategic CSR and its benefits is presented by Werther Jr and Chandler (2005). They perceive it as global brand insurance. They notice that some factors, like growing integration of strategy, brand management and need for social responsibility, push CSR to change its significance from being only some kind of social supplement to becoming a strategic necessity. Moreover, stakeholders perceive CSR influence more strongly when a brand is a vital element of corporate strategy. The CSR significance to any firm raises proportionally to the company's global brand value. The researchers also state that CSR can bring to enterprises a sustainable competitive advantage by introducing right balance between strategy, brand management and CSR. Werther Jr and Chandler (2005) understand CSR as including common good policies in corporate strategies, cultures and decision making processes meeting stakeholders' expectations. They also link CSR with creating strategies which allow them to achieve successes and make their brands perceived better in environments where they operate. Taking all of this issues into consideration, Werther Jr and Chandler (2005) see "strategic CSR as global brand insurance".

Strategic CSR can create a lot of benefits both for business and societies. Appropriately formulated and implemented it can positively influence firm's performance. Nevertheless, analyzing strategic consequences of CSR requires taking into consideration many different factors, such as cultural differences between countries, institutions and stakeholders. It can lead to miscellaneous expectations and approaches to operate. It is also connected with taking decisions, which actions to involve in, how much to invest in them. Differences in culture cause also other results of CSR activities. It is related to the necessity of conducting appropriate analysis and thinking over company's strategy in the area of CSR (McWilliams et al., 2006).

Husted and Allen (2007) identify five strategic dimensions of CSR projects: visibility, appropriability, voluntarism, centrality and proactivity. They conducted the study among Spanish companies. Its 
objective was to study which of these five dimensions was crucial for enterprises to create value through CSR activities. They also characterize all of these dimensions according to three areas: traditional CSR, traditional strategy and strategic CSR. First, traditional CSR is considered from the perspectives of those dimensions. Thus, as regards visibility and appropriability, it is not relevant. Providing well-being is a reward in itself and brings profits in long term. From the perspective of voluntarism, traditional CSR manifests in taking part in social activities going beyond those which are demanded by the company's interests and the law. Regarding centrality, it is not relevant. Providing good is linked to societal needs, not to core business mission. Last, proactivity provides modifications in social issues. The next approach is traditional strategy and it is also considered from the point of view of five strategic CSR dimensions. Thus, regarding visibility, a traditional strategy aims at building awareness of products and brands among customers. Considering appropriability, a traditional strategy creates added value for the company by managing relationships with suppliers, customers and competitors. From the voluntarism perspective, a traditional strategy is connected with the firm' innovation which is linked with its ability to learn. As regards centrality, a traditional strategy is aimed at creating value throughout product or service innovations. Regarding proactivity, it is connected with the first-mover advantage. The next approach is strategic CSR. From the perspective of visibility, it is aimed at building awareness of customers and stakeholders, while creating CSR added value. Regarding appropriability, strategic CSR creates added value for a company by managing relationships with its stakeholders. Considering voluntarism, it is connected with taking part in social activities going beyond those required by law. As regards centrality, it creates value throughout product or service innovations connected with social issues. Last but not least, proactivity provides modifications in social issues presenting market opportunities (Husted \& Allen, 2007).

Husted and Allen (2007) state that a very significant issue to develop a theory of strategic CSR is to explore and understand under which conditions CSR may create value. According to the study conducted by the researchers, only three of five strategic dimensions are related to value creation in perception of Spanish firms under the study. These are visibility, appropriability and voluntarism. Creating valuable CSR strategy can be connected with considering these variables. However, to 
create some added value for the company, it may be sufficient to focus on even just one of them.

There are numerous factors influencing strategic CSR and deciding whether it will be successful or not, whether it will generate benefits only for the company, only for societies, or maybe for both. Lantos (2001) provides some suggestions for strategic CSR. He indicates a few crucial factors, which are important for strategic CSR:

- senior management leadership: influence of the most important people in an organization is vital. Their commitment to strategic CSR is key, because their behaviors should serve as a model to other employees (Lantos, 2001). Managers should also determine how their companies could become more socially responsible, ecologically sustainable and economically competitive (Orlitzky et al., 2011);

- marketing: marketing activities should create values to society and also create benefits for the company (Lantos, 2001);

- common ground: corporate leaders should act according to CSR values to encourage other employees and teams to invent and innovate new ideas connected with CSR to make everyone in a company involved in actions (Lantos, 2001);

- mission and vision statements: it helps to clarify enterprise's commitment to CSR as well as to motivate employees, e.g. setting up measurable and achievable goals according to CSR activities (Lantos, 2001).

Incorporating CSR into strategy is a crucial stage of adopting the CSR concept to businesses' operations. Strategy can be perceived as a guidepost for a company's scope of operation, establishing its position in the market, how a firm competes, and for its existence in general. Galbreath (2009) states that in order to better integrate CSR and strategy, firms need to answer some questions and follow that approach. According to that, he emphasizes six crucial dimensions of strategy (Galbreath, 2009):

- mission: what are companies' long term goals?;

- strategic issues: what are internal and external factors influencing whether firms are able to act in line with their missions?;

- markets: where should enterprises compete?;

- customer needs: what products and services should be offered to customers in particular markets?; 
- resources: what internal resources are needed to be able to compete?;

- competitive advantage: what to do to be better than competitors?

Galbreath (2009) adds that CSR should be connected with each of these components/dimensions to appropriately integrate CSR with a strategy and to achieve higher performance and benefits. Therefore, firms have to consider all of six dimensions mentioned above in order to address CSR more strategically. Moreover, businesses, which understand better their responsibilities towards societies and which recognize more appropriately how they could build CSR into strategy, will more probably gain privileged competitive positions and create benefits for stakeholders and societies. Firms engage in social activities that not only generate profits, but also offer some benefits to the society. "This implies that strategic CSR is far more than ad-hoc approach or a bolt on to strategy or something that is strategic only when viewed within the realm of a singular dimension of a firm's responsibilities, such as the discretionary responsibility" (Galbreath, 2009). Considering CSR with six dimensions mentioned and described above, it can better integrated into a corporate strategy.

Recently, there can be observed an intensified debate regarding the CSR concept, and building it into strategy and incorporating into firms' strategies (Galbreath, 2009). A strategic role of CSR gains an importance for managers and they have to take it into consideration while creating companies' strategies. Porter and Kramer (2006) state that CSR becomes a priority for numerous enterprises. However, they need to be more effective in this field, and perceive CSR as their strategic goals and pay more attention to social and environmental issues. They can do it, e.g. by developing some initiatives like ecoinnovations. This kind of activities/products can be beneficial both for companies, and societies and the natural environment. It is line with the nature of strategic CSR, for which one of the key assumptions is achieving a win-win effect.

\section{Conclusions}

The importance of the CSR concept is still growing. It is driven by many factors, like e.g. increasing social expectations, more benefits for companies from such activities. Some firms do it voluntarily, some of 
them for money gains. Nevertheless, there is no doubt that this idea can be beneficial for every party involved in these actions. Thus, in order to create benefits also for companies, managers need to rethink their CSR activities, plan them in an appropriate way. Relations between business and society are very relevant for the functioning of the whole economy. Thus, the CSR concept can be a core of these processes and can be beneficial also for economies.

To sum up, in recent years it can be observed a growing interest and debate about the CSR concept and especially converting it into an appropriate strategy linking it with other company's activities. CSR and its strategic role become more and more important and managers need to incorporate CSR assumptions into firm strategies. These kind of operations can generate benefits for companies, societies and the natural environment, thus it is in accordance with the idea and assumptions of strategic CSR. However, it is very important to understand and explore under which conditions CSR may create value. The CSR concept is very broad and comprehensive, so there can be identified numerous aspects, which need to be linked to each other in order to create values both for societies and companies. Thus, creating CSR strategies and incorporating them into firms' strategies can be a crucial step to company's success.

\section{References}

Baron, D. P. (2001). Private politics, corporate social responsibility, and integrated strategy. Journal of Economics and Management Strategy, 10(1), 7-45.

Czakon, W. (2011). Metoda systematycznego przeglądu literatury. Przegląd Organizacji, 3, 57-62.

Czerniachowicz, B., Lis, A., \& Wieczorek-Szymańska, A. (2017). The relationships between leadership and corporate social responsibility: Systematic literature review. Journal of Corporate Responsibility and Leadership, 4(3), 9-23.

Dawkins, J., \& Lewis, S. (2003). CSR in stakeholder expectations: And their implication for company strategy. Journal of Business Ethics, 44(2-3), 185-193.

Galbreath, J. (2009). Building corporate social responsibility into strategy. European Business Review, 21(2), 109-127.

Husted, B. W., \& Allen, D. B. (2007). Strategic corporate social responsibility and value creation among large firms. Lessons from the Spanish experience. Long Range Planning, 40(6), 594-610.

Józefowicz, B. (2017). Diversity management and trust: Systematic literature review. Journal of Corporate Responsibility and Leadership, 4(4), 51-68.

Lantos, G. P. (2001). The boundaries of strategic corporate social responsibility. Journal of Consumer Marketing, 18(7), 595-630. 
Lis, A. (2017). Relacyjny wymiar zdolności organizacji do absorpcji wiedzy zewnętrznej. Organizacja i Kierowanie, 2(176), 313-328.

Lis, A., \& Sudolska, A. (2018). W poszukiwaniu typologii innowacji społecznie odpowiedzialnych: Mapowanie pola badawczego. Studia i Prace Wydziału Nauk Ekonomicznych i Zarzq̨dzania Uniwersytetu Szczecińskiego, 52(2), 115-125.

McWilliams, A., \& Siegel, D. S. (2011). Creating and capturing value: Strategic corporate social responsibility, resource-based theory, and sustainable competitive advantage. Journal of Management, 37(5), 1480-1495.

McWilliams, A., Siegel, D. S., \& Wright, P. M. (2006). Corporate social responsibility: Strategic implications. Journal of Management Studies, 43(1), 1-18.

Orlitzky, M., Siegel, D. S., \& Waldman, D. A. (2011). Strategic corporate social responsibility and environmental sustainability. Business and Society, 50(1), 6-27.

Perrini, F., Russo, A., \& Tencati, A. (2007). CSR strategies of SMEs and large firms. Evidence from Italy. Journal of Business Ethics, 74(3), 285-300.

Porter, M. E., \& Kramer, M. R. (2006). Strategy \& society: The link between competitive advantage and corporate social responsibility. Harvard Business Review, December, 78-92.

Siegel, D. S., \& Vitaliano, D. F. (2007). An empirical analysis of the strategic use of corporate social responsibility. Journal of Economics and Management Strategy, 16(3), 773-792.

Ślęzak, M., \& Jagielski, M. (2018). Manifestations and measures of frugal innovations. Journal of Corporate Responsibility and Leadership, 5(4), 81-104.

Werther Jr., W. B., \& Chandler, D. (2005). Strategic corporate social responsibility as global brand insurance. Business Horizons, 48(4), 317-324. 
